\title{
Meat lipid profile of steers finished in pearl millet pasture with different rates of concentrate
}

\author{
Luis Fernando Glasenapp de Menezes ${ }^{(1)}$, Luciane Rumpel Segabinazzi(1), João Restle(2), \\ Leandro da Silva Freitas ${ }^{(3)}$, Ivan Luiz Brondani( ${ }^{(4)}$, Magali Floriano da Silveira( ${ }^{(1)}$, \\ Rangel Fernandes Pacheco ${ }^{(4)}$, Perla Cordeiro de Paula(4) and Guilherme Joner ${ }^{(4)}$
}

\begin{abstract}
(1)Universidade Tecnológica Federal do Paraná, Departamento de Zootecnia, Estrada da Boa Esperança, Km 04, CEP 85660-000 Dois Vizinhos PR. E-mail: Ifgdm@yahoo.com.br, luzoot@hotmail.com, mg_flor@yahoo.com.br (2)Universidade Federal do Tocantins, Departamento de Ciência Animal Tropical, BR 153, Km 112, CEP 77804970 Araguaína, TO. E-mail: joresttle@terra.com.br (3)|nstituto Federal Farroupilha, Rodovia RS 377, Km 27, CEP 97555000 Alegrete, RS. Email: freitaszoot@hotmail.com ${ }^{(4)}$ Universidade Federal de Santa Maria, Departamento de Zootecnia, Avenida Roraima, 1.000, Camobi, CEP 97105-900 Santa Maria, RS. Email: brondani@pq.cnpq.br, rangelzootec@hotmail.com, perla.zoot@gmail.com, jonerzootecnista@hotmail.com
\end{abstract}

\begin{abstract}
The objective of this work was to evaluate the meat lipid profile from Devon beef steers finished in pearl millet (Pennisetum americanum) pasture and fed at different rates of concentrate supplementary diet. Twelve steers weighing $270 \mathrm{~kg}$, at 12-month-average initial age, were randomly distributed into three treatments: pearl millet pasture; and pearl millet pasture plus a concentrate equivalent at 0.5 or $1.0 \%$ of body weight, with two replicates. Total contents of saturated and unsaturated fatty acids, the polyunsaturated:saturated ratio and other relevant fatty acids as the vaccenic acid, conjugated linoleic acid, omega-3, and omega- 6 were not affected by the consumption of a concentrate supplement at 0.5 or $1.0 \%$ live weight. However, the $0.5 \%$ supplementation level reduced the concentration of dihomo- $\gamma$-linolenic fatty acid (C20:3n-6), while the $1.0 \%$ supplementation level elevated the content of docosahexaenoic (DHA) (C22: $6 \mathrm{n}-3)$ fatty acid, and the omega-6:omega-3 ratio in meat. Consumption of up to $1.0 \%$ energy supplementation increases the omega-6:omega-3 ratio in meat from Devon steers grazing on pearl millet pasture.
\end{abstract}

Index terms: Pennisetum americanum, conjugated linoleic acids, fatty acids, omega-3, tropic pasture, wheat bran.

\section{Perfil lipídico da carne de novilhos terminados em pastagem de milheto com diferentes taxas de concentrado}

\begin{abstract}
Resumo - O objetivo deste trabalho foi avaliar o perfil lipídico da carne de novilhos Devon, terminados em pastagem de milheto (Pennisetum americanum) e alimentados com dieta suplementar de um concentrado a diferentes taxas. Doze animais, com $270 \mathrm{~kg}$ e idade média inicial de 12 meses, foram distribuídos ao acaso, em três tratamentos: pastagem de milheto; pastagem de milheto e suplemento concentrado a 0,5 ou $1,0 \%$ do peso corporal, com duas repetições. Os teores totais de ácidos graxos saturados e insaturados, a relação poli-insaturados:saturados e outros ácidos relevantes como o vacênico, o linoleico conjugado, o ômega-3 e ômega-6 não foram influenciados pelo consumo de suplemento concentrado a 0,5 ou $1,0 \%$ do peso vivo. Entretanto, a suplementação a $0,5 \%$ reduziu a concentração do ácido graxo dihomo- $\gamma$-linolênico (C20:3 n-6), enquanto a suplementação a 1,0\% elevou o teor do ácido graxo docosahexaenoico (DHA) (C22:6 n-3) e a relação ômega-6:omega-3 na carne. O consumo de até 1,0\% de suplemento energético aumenta a relação ômega-6:ômega-3 na carne de novilhos Devon mantidos em pastagem de milheto.
\end{abstract}

Termos para indexação: Pennisetum americanum, ácido linoleico conjugado, ácidos graxos, ômega-3, pastagem tropical, farelo de trigo.

\section{Introduction}

The lipid profile of meat can be influenced by breed, sex, duration and type of feeding among others (Wood et al., 2008; Menezes et al., 2009; Rossato et al., 2010). Basarab et al. (2007) showed that animals finished on pasture produced meat with more favorable relations of polyunsaturated:saturated fatty acids (PUFA:SFA) and omega-6:omega-3 $(\omega-6 / \omega-3)$ than those feedlot-finished animals, since the roughage contained higher levels of linolenic fatty acid (C18:3 n-3), while grains were rich in linoleic fatty acids (C18:2 n-6). 
A supplementation diet with grain for cattle kept on pasture can be used as a strategy to increase individual weight gain, as well as to rise the stocking rate per hectare. With fat input from grain, energy supplementation can contribute with higher amount of unsaturated fatty acids (UFA), and also promote changes in the digestive processes in the rumen, like the passage rate increase, and ruminal $\mathrm{pH}$ reduction. Therefore, supplementation with grain predisposes to lower rates of biohydrogenation and larger input of UFA which reach the small intestine to be absorbed (Martínez Marín, 2007). Even so, the pasture type appears to be an important factor in the process of lipid deposition in beef, since tropical pastures show a lipid profile with lower levels of polyunsaturated fatty acids (PUFA), mainly C18:3 and smaller amounts of C14:0, in comparison to temperate pastures (Menezes et al., 2010).

The objective of this work was to evaluate the meat lipid profile from Devon beef steers finished in pearl millet (Pennisetum americanum) pasture and fed at different rates of concentrate supplementary diet.

\section{Materials and Methods}

The experiment was carried out in the Department of Animal Science, Universidade Federal de Santa Maria (UFSM), RS, at $29^{\circ} 43^{\prime} \mathrm{S}, 53^{\circ} 42^{\prime} \mathrm{W}, 95 \mathrm{~m}$ altitude. Climate is classified as humid subtropical (Moreno, 1961), and the soil mapping belongs to São Pedro unit, classified as Paleudalf (red-yellow podzolic) (Streck et al., 2002).

Twelve Devon steers, weighing $270 \mathrm{~kg}$, with 12-month-average initial age, were kept in a pearl millet (Pennisetum americanum L. Leeke) pasture, and were subjected to the following feeding treatments: only pearl millet grazing; pearl millet plus concentrate at $0.5 \%$ of body weight; and pearl millet plus concentrate at $1.0 \%$ of body weight.

The continuous grazing system with variable stocking rate was used, as described by Mott \& Lucas (1952), with an offer of leaf blades dry matter (DM) kept at $10 \%$ of body weight. Two pasture replicates per treatment were used, with two tester animals each one, where regulator animals were eventually also allocated. Samples of the concentrate supplement and of the pasture (by simulating grazing) were collected to determine the chemical composition and fatty acid profile of consumed materials (Table 1).
The pasture showed $29.90 \%$ dry matter (DM), $9.63 \%$ crude protein (CP), 2.87 Mcal digestible energy (DE) per kg DM, and 53.82\% NDF. Animals exclusively finished on pasture had free access to salt. The animals of the supplementary treatment received a daily concentrate diet at $14 \mathrm{~h}$, which was composed of wheat bran, limestone, sodium chloride and monensin, totaling an energy supplement with $13.9 \% \mathrm{CP}$ and $71.4 \% \mathrm{TDN}$.

After 100 days of grazing, the animals with $375.8 \mathrm{~kg}$ average weight were slaughtered in a commercial slaughterhouse, after 14-hour complete fast. The slaughter process followed the normal flow of the establishment, in accordance with the Regulation of Industrial and Sanitary Inspection of Animal Products. After carcass cooling for 24 hours at $1{ }^{\circ} \mathrm{C}$, samples of the longissimus dorsi muscle were removed, packed, and frozen for subsequent analysis of fatty acid profile.

To determine fatty acids in the samples, lipids were initially extracted by using the method of Bligh \& Dyer (1959) and, then, they were esterified according to Hartman \& Lago (1973), and analyzed in an Agilent 6890 Gas Chromatograph (Hewlett-Packard, Palo

Table 1. Fatty acid profile of pearl millet and concentrate (g $100 \mathrm{~g}^{-1}$ fat tissue in natura).

\begin{tabular}{|c|c|c|c|}
\hline $\begin{array}{l}\text { Fatty } \\
\text { acids }\end{array}$ & $\begin{array}{c}\text { Usual } \\
\text { nomenclature }\end{array}$ & $\begin{array}{l}\text { Tropical } \\
\text { pasture }\end{array}$ & Concentrate \\
\hline C12:0 & Lauric acid & 2.46 & - \\
\hline C14:0 & Myristic acid & 0.30 & 0.16 \\
\hline C16:0 & Palmitic acid & 24.39 & 20.00 \\
\hline C16:1 & Palmitoleic acid & 0.34 & 0.17 \\
\hline $\mathrm{C} 17: 0$ & Margari acid c & 0.32 & 0.24 \\
\hline C18:0 & Stearic acid & 4.75 & 2.38 \\
\hline C18:1 n-9 cis & Oleic acid & 7.54 & 22.15 \\
\hline C18:2 n-6 cis & Linoleic acid & 16.18 & 44.46 \\
\hline C18:3 n-3 & Linolenic acid & 22.74 & 2.79 \\
\hline C19:0 & N-nonadecylic acid & 0.18 & - \\
\hline C20:0 & Arachidic acid & 1.04 & 0.43 \\
\hline $\mathrm{C} 20: 1$ & 11-eicosaenoic acid & - & 1.05 \\
\hline $\mathrm{C} 21: 0$ & Heneicosanoic acid & - & 0.08 \\
\hline $\mathrm{C} 20: 2$ & 11.14-eicosadienoic acid & 0.19 & 0.18 \\
\hline $\mathrm{C} 22: 0$ & Behenic acid & 2.36 & 0.45 \\
\hline $\mathrm{C} 23: 0$ & Tricosanoic acid & 0.33 & 0.10 \\
\hline $\mathrm{C} 24: 0$ & Lignoceric acid & 2.61 & 0.42 \\
\hline Saturated (SFA) & - & 38.75 & 24.18 \\
\hline Unsaturated & - & 47.20 & 70.80 \\
\hline Polyunsaturated (PUFA) & - & 39.32 & 47.43 \\
\hline PUFA:SFA & - & 1.01 & 1.96 \\
\hline$\omega-6$ & Omega-6 & 16.18 & 44.46 \\
\hline$\omega-3$ & Omega-3 & 22.74 & 2.79 \\
\hline$\omega-6 / \omega-3$ & Omega-6:Omega-3 & 0.71 & 15.93 \\
\hline
\end{tabular}


Alto, CA, USA), equipped with a flame ionization detector (FID) and a capillary column SP-2560 $100 \mathrm{~m}$ x 0.25 mm x $0.2 \mu \mathrm{m}$ (Supelco, Sigma-Aldrich, São Paulo, SP, Brazil). The temperature gradient used for ester separation of fatty acids was: $140^{\circ} \mathrm{C}$ for $5 \mathrm{~min}$, increasing $1.6^{\circ} \mathrm{C}$ per min up to $210^{\circ} \mathrm{C}$, remaining for additional $10 \mathrm{~min}$; increasing $10^{\circ} \mathrm{C}$ per min up to $240^{\circ} \mathrm{C}$, staying for another $15 \mathrm{~min}$, totaling a run of $76 \mathrm{~min}$. Gas (N2) flow was $30 \mathrm{~mL}$ per min, and the volume of injection was $1 \mu \mathrm{L}$ with 1:50 split ratio. Thus, the identification of fatty acids was carried out by comparing the retention time of fatty acids from the samples with known standards.

The experimental design was completely randomized. Data analysis of variance was done by GLM procedure, and variables were tested with Shapiro-Wilk normality. The mathematic model was: $Y_{i j k}=\mu+\beta_{i}+\varepsilon_{i j k}-i$, in which: $Y_{i j k}$ represents the dependent variables; $\mu$ is the overall mean of the observations; $\beta_{\mathrm{i}}$ is the effect of dietary treatment, and $\varepsilon_{\mathrm{ijk}}$ is the residual random error $\operatorname{NID}\left(0, \sigma^{2}\right)$. The means were classified by the $\mathrm{F}$ test, and the parameters with significant effect were compared by t test, at $5 \%$ probability. Statistical analyses were performed with the aid of SAS software.

\section{Results and Discussion}

The different levels of energy supplementation did not alter the levels of saturated fatty acids (SFA) in meat (Table 2). Using stored forage, Menezes et al. (2010) observed that the consumption of pearl millet silage, compared to annual ryegrass silage, promotes

Table 2. Profile of saturated fatty acids in longissimus dorsi muscle of beef steers grazing pearl millet and feeding a supplementation diet $(0.5 \%$ and $1.0 \%)$ at different rates ( $100 \mathrm{~g}^{-1}$ of fat tissue in natura).

\begin{tabular}{|c|c|c|c|c|c|c|}
\hline \multirow[t]{2}{*}{ Fatty acids } & \multicolumn{3}{|c|}{ Feeding system } & \multirow[t]{2}{*}{ Mean } & \multirow[t]{2}{*}{ SE } & \multirow[t]{2}{*}{$\mathrm{p}$} \\
\hline & $\begin{array}{l}\text { Only } \\
\text { millet }\end{array}$ & $\begin{array}{c}\text { Millet + } \\
0.5 \% \\
\end{array}$ & $\begin{array}{c}\text { Millet + } \\
1.0 \% \\
\end{array}$ & & & \\
\hline Myristic C14:0 & 1.41 & 1.52 & 1.60 & 1.51 & 0.18 & 0.76 \\
\hline Pentadecanoic C15:0 & 0.29 & 0.10 & 0.29 & 0.22 & 0.06 & 0.14 \\
\hline Palmitic C16:0 & 22.59 & 22.26 & 23.20 & 22.68 & 0.98 & 0.79 \\
\hline Margaric C17:0 & 0.95 & 1.33 & 0.87 & 1.05 & 0.25 & 0.42 \\
\hline Stearic C18:0 & 20.00 & 19.39 & 18.26 & 19.22 & 0.81 & 0.36 \\
\hline Nonadecylic C19:0 & 1.16 & 1.09 & 0.93 & 1.06 & 0.49 & 0.94 \\
\hline Behenic C20:0 & 0.16 & 0.07 & 0.06 & 0.10 & 0.04 & 0.29 \\
\hline Saturated & 45.43 & 44.78 & 44.29 & 44.83 & 1.42 & 0.85 \\
\hline
\end{tabular}

SE, standard error; $p$, probability. a higher intake of SFA; however, the total of SFA that reaches the small intestine for absorption is similar. This may explain the insignificant change in the levels of SFA in meat from cattle, in the present and in other studies, such as that by Prado et al. (2003).

Stearic fattyacid(C18:0)accountedforapproximately $19.22 \%$ of total fatty acids (Table 2 ). This value was $18 \%$ lower than that reported by Prado et al. (2003) for meat of steers grazing pearl millet. Although saturated, this fatty acid is considered neutral because it can be transformed into oleic fatty acid (C18:1 cis9), which is considered a hypocholesterolemic acid because it acts to reduce LDL-cholesterol, and to increase high-density lipoprotein (HDL) levels.

Monounsaturated fatty acids (MUFA) were similar

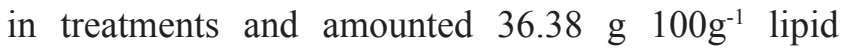
(Table 3). The addition of unsaturated fatty acids in meat may result from the increase of unsaturated fat intake, since about $20 \%$ UFA ingested by ruminants reaches the small intestine without undergoing complete biohydrogenation (Martínez Marin, 2007). Furthermore, the increase of this type of fatty acids in beef may be originated from the action of factors that inhibit complete biohydrogenation, as the inclusion of

Table 3. Profile of unsaturated, long-chain fatty acids in longissimus dorsi muscle of beef steers grazing millet and receiving different levels $(0.5 \%$ and $1.0 \%)$ of supplementation ( $\mathrm{g} 100 \mathrm{~g}^{-1}$ of fat tissue in natura $)^{(1)}$.

\begin{tabular}{|c|c|c|c|c|c|c|}
\hline \multirow{2}{*}{$\begin{array}{l}\text { Fatty } \\
\text { acids }\end{array}$} & \multicolumn{3}{|c|}{ Feeding system } & \multirow{2}{*}{ Mean } & \multirow[t]{2}{*}{$\mathrm{SE}$} & \multirow[t]{2}{*}{$\mathrm{p}$} \\
\hline & $\begin{array}{l}\text { Only } \\
\text { millet }\end{array}$ & $\begin{array}{c}\text { Millet }+ \\
0.5 \%\end{array}$ & $\begin{array}{c}\text { Millet }+ \\
1.0 \%\end{array}$ & & & \\
\hline Palmitoleic C16:1 & 1.95 & 2.02 & 2.29 & 2.09 & 0.23 & 0.58 \\
\hline Oleic C18:1 n-9 trans & 0.14 & 0.30 & 0.12 & 0.19 & 0.15 & 0.67 \\
\hline Vaccenic C18:1 trans-11 & 1.97 & 1.74 & 1.67 & 1.79 & 0.15 & 0.41 \\
\hline Oleic C18:1 n-9 cis & 30.88 & 30.07 & 32.48 & 1.14 & 1.34 & 0.46 \\
\hline Gadoleic C20:1 & 0.07 & 0.04 & 0.08 & 0.06 & 0.03 & 0.77 \\
\hline Monounsaturated & 35.05 & 34.59 & 36.71 & 35.45 & 1.40 & 0.56 \\
\hline C18:2 n-6 cis (linoleic) & 3.87 & 3.21 & 3.70 & 3.59 & 0.50 & 0.64 \\
\hline $\mathrm{C} 18: 3 \mathrm{n}-3$ cis (linolenic) & 1.17 & 0.84 & 0.76 & 0.92 & 0.15 & 0.20 \\
\hline CLA & 0.31 & 0.32 & 0.20 & 0.28 & 0.10 & 0.68 \\
\hline C20:2 (eicosadienoic) & 0.04 & 0.06 & 0.02 & 0.04 & 0.04 & 0.80 \\
\hline$C 20: 3 n-6^{(2)}$ & $0.37 \mathrm{a}$ & $0.10 \mathrm{~b}$ & $0.38 \mathrm{a}$ & 0.28 & 0.07 & 0.04 \\
\hline C20:5 n-3 EPA ${ }^{(3)}$ & 0.91 & 0.62 & 0.56 & 0.70 & 0.13 & 0.21 \\
\hline $\mathrm{C} 22: 6 \mathrm{n}-3^{(4)}$ & $0.04 \mathrm{~b}$ & $0.00 \mathrm{~b}$ & $0.09 \mathrm{a}$ & 0.05 & 0.02 & 0.12 \\
\hline Polyunsaturated & 6.56 & 5.15 & 5.89 & 5.87 & 0.80 & 0.50 \\
\hline Total unsaturated & 41.61 & 39.76 & 42.60 & 41.33 & 1.38 & 0.38 \\
\hline Unidentified fatty acids & 11.80 & 14.36 & 12.18 & 12.78 & 1.56 & 0.48 \\
\hline
\end{tabular}

Pesq. agropec. bras., Brasília, v.48, n.5, p.553-558, maio 2013 DOI: 10.1590/S0100-204X2013000500012 
concentrates in the diet. In this case, nutritional factors, such as the increasing rate of passage of digesta, and ruminal $\mathrm{pH}$ reduction may hinder the action and development of rumen bacteria which act in the process of biohydrogenation like Butyrivibrio fibrisolvens, which requires a minimum $6.2 \mathrm{pH}$ (Furlan et al., 2006).

The content of oleic acid (C18:1 n-9 cis) did not differ by the use of supplementation, likewise observed in the studies of Prado et al. (2003). It was expected that the raise of concentrate supplementation, whose content of polyunsaturated fatty acids is high (Table 1), could result in a small reduction in rumen $\mathrm{pH}$, and, consequently, in an incomplete biohydrogenation of fatty acids (Loor et al., 2004); this fact would result in higher levels of monounsaturated acids; however, which did not occur in the present study.

The content of vaccenic acid (C18:1 trans-11) was similar between treatments and showed $1.79{\mathrm{~g} 100 \mathrm{~g}^{-1}}^{-1}$ average intramuscular fat. This fatty acid is considered the precursor of the conjugated linoleic acids (CLA) that can be formed from the action of the enzyme Delta 9-desaturase, which is present in the adipose tissue of animals (Ledoux et al., 2000). The reducing effects of the total biohydrogenation process seem to be more intense, when the inclusion of concentrate in the diet is elevated, which results in the increase of duodenal flow of C18:0 trans-11 (Menezes et al., 2010). Therefore, energy supplementation used in the present study seems not to have been effective on ruminal biohydrogenation, since it caused no changes of the concentrations of vaccenic acid and CLA cis-9-trans-11. The production of CLA can also be related to higher intake of polyunsaturated fatty acids, especially linoleic acid (Duynisveld et al., 2006); however, the high content of this fatty acid in the concentrate fraction of the diet (Table 1) was not enough to promote changes in the CLA content in meat from animals grazing pearl millet. In grazing systems, other factors such as the proportions of leaf and stem, as well as the forage maturity, may determine the percentage of PUFA (Boufaïed et al., 2003).

There was no difference on meat contents of eicosatrienoic PUFA (C20:3 n-6) between treatments not supplemented and supplemented with concentrate at $1.0 \%$ of body weight. However, the content of C20:3 $\mathrm{n}-6$ in treatmente with pearl millet $+0.5 \%$ concentrate was lower. These long-chain acids come from the chain elongation performed by the elongase and desaturase enzymes that allow linoleic acid (C18:2 n-6) to be metabolized into: $\gamma$-linolenic acid (C18:3 n-6), dihomo- $\gamma$-linolenic (C20:3 n-6) acid, and arachidonic (C20:4 n-6) acid; and the $\alpha$-linolenic (C18:3 n-3) into other acids of the omega-3 series like eicosapentaenoic (EPA) (C20:5 n-3) and docosahexaenoic (DHA) (C22:6 n-3) acids (Tanaka, 2005). These last two are sought to improve the quality of beef lipid. Tanaka (2005) also reports that the accumulation of CLA can modulate the synthesis of dihomo- $\gamma$-linolenic acid (C20:3 n-6) and arachidonic (C20:4 n-6), as it competes with linoleic acid (C18:2 n-6) for the same enzyme, Delta 6 -desaturase, to form the $\alpha$-linolenic (C18:3 n-3) in their derivatives. A factor that may have contributed to reduce the $\omega-6 / \omega-3$ ratio in treatments without supplementation and with 0.5 concentrate supplementation (Table 4) was the high content of linolenic acid (C18: 3 n-3) in pearl millet (22.74 $\mathrm{g} 100 \mathrm{~g}^{-1}$ of total lipids of forage). In their study, Menezes et al. (2010) found that animals fed a restricted diet with tropical pasture silage (pearl millet + Alexander grass) ingested a higher amount of omega- 3 fatty acids (9.5 g per day) compared to those fed ryegrass silage $\left(3.43 \mathrm{~g} \mathrm{~d}^{-1}\right)$ or a diet containing $60 \%$ corn silage and $40 \%$ concentrate $\left(5.89 \mathrm{~g} \mathrm{~d}^{-1}\right)$, and showed relations omega-6:omega-3, 1.55, 1.13 and 5.72, respectively.

Besides pasture type, pasture management can also influence fatty acid composition of the forage, since a great part of fatty acids, like C18:3 n-3, C18:2 and C16:0, which are the main fatty acids, is found in forage leaves (Boufaïed et al., 2003). The exclusive use of pearl millet, according to Gonçalves \& Quadros (2003), results in animals with lower stocking rate than

Table 4. Profile of fatty acids $\omega-6, \omega-3, \omega-6 / \omega-3$ ratio, and polyunsaturated fatty acids: saturated (PUFA:SFA), in longissimus dorsi muscle of beef steers grazing millet and receiving different levels $(0.5 \%$ and $1.0 \%)$ of

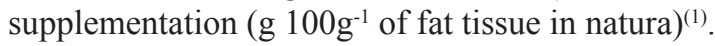

\begin{tabular}{lllllll}
\hline Fatty & \multicolumn{3}{c}{ Feeding system } & Average & SE & $\mathrm{p}$ \\
\cline { 2 - 5 } acids & $\begin{array}{l}\text { Only } \\
\text { millet }\end{array}$ & $\begin{array}{c}\text { Millet }+ \\
0.5 \%\end{array}$ & $\begin{array}{c}\text { Millet }+ \\
1.0 \%\end{array}$ & & & \\
\hline$\omega-6(\%)$ & 4.07 & 3.30 & 4.25 & 3.87 & 0.55 & 0.47 \\
$\omega-3(\%)$ & 2.14 & 1.47 & 1.42 & 1.67 & 0.29 & 0.20 \\
$\omega-6 / \omega-3$ & $1.97 \mathrm{~b}$ & $2.21 \mathrm{~b}$ & $3.10 \mathrm{a}$ & 2.42 & 0.24 & 0.02 \\
PUFA:SFA & 0.12 & 0.09 & 0.12 & 0.11 & 0.02 & 0.55 \\
\hline
\end{tabular}

${ }^{(1)}$ Means followed by different letters, in the same row, differ by $\mathrm{t}$ test, at $5 \%$ probability. SE,standard error; $p$, probability. 
that of supplemented animals. Thus, lower stocking rate allows animals a greater opportunity to select the pasture and, therefore, to have food intake of better quality, since the diet is composed of the younger leaves, which are photosynthetically more active and of better digestibility (Boufaïed et al., 2003). Furthermore, the higher proportion of total fatty acids is directly related to the proportion of leaf: stem ratio, which is higher in the initial stage of the pasture or when the grazing intensity is moderate.

Differently from the observations of French et al. (2000), who concluded that the intake increasing of concentrate, in diets rich in fresh forage, results in a linear increase in the PUFA:SFA ratio in intramuscular fat, the supplementation used in the present work did not show to be relevant in the handling of this relation, whose average value was 0.11 , very similar to 0.10 considered typical for beef cattle (French et al., 2000), and much lower than 0.45 , as recommended by health agencies and reported by Wood et al. (2004).

\section{Conclusions}

1. Supplementation with concentrate at $1.0 \%$ of body weight, in the finishing phase of Devon steers grazing pearl millet, does not alter the total levels of saturated fat or unsaturated fat, and conjugated linoleic acids of Devon steer meat.

2. Supplementation with concentrate at $0.5 \%$ reduces the concentration of dihomo- $\gamma$-linolenic (C20:3 n-6); however, supplementation at $1.0 \%$ increases the content of docosahexaenoic (C22:6 n-3) and the $\omega-6 / \omega-3$ ratio in meat of Devon steers.

\section{References}

BASARAB, J.A.; AALHUS, J.L.; SHAH, M.A.; BARON, V.S.; OKINE, E.K.; ROBERTSON, W.M. Effect of sunflower seed supplementation on the fatty acid composition of muscle and adipose tissue of pasture-fed and feedlot finished beef. Canadian Journal of Animal Science, v.87, p.71-86, 2007. DOI: 10.4141/ A06-048.

BLIGH, E.G.; DYER, W.J. A rapid method of total lipid extraction and purification. Canadian Journal of Biochemistry and Physiology, v.37, p.911-917, 1959. DOI: 10.1139/o59-099.

BOUFAÏED, H.; CHOUINARD, P.Y.; TREMBLAY, G.F.; PETIT, H.V.; MICHAUD, R.; BÉLANGER, G. Fatty acids in forages. I. Factors affecting concentrations. Canadian Journal of Animal Science, v.83, p.501-511, 2003. DOI: 10.4141/A02-098.
DUYNISVELD, J.L.; CHARMLEY, E.; MIR, P. Meat quality and fatty acid composition of pasture finished beef steers fed barley and soybeans. Canadian Journal of Animal Science, v.86, p.535-545, 2006. DOI: 10.4141/A06-004.

FRENCH, P.; STANTON, C.; LAWLESS, F.; O'RIORDAN, E.G.; MONAHAN, F.J.; CAFFREY P.J.; MOLONEY, A.P. Fatty acid composition, including conjugated linoleic acid, of intramuscular fat from steers offered grazed grass, grass silage, or concentrate-based diets. Journal Animal of Science, v.78, p.2849-2855, 2000.

FURLAN, R.I.; MACARI, M.; FARIA FILHO, D.E. Anatomia e fisiologia do trato intestinal. In: BERCHIELLI, T.T.; PIRES, A.V.; OLIVEIRA, S.G. de (Ed.). Nutrição de ruminantes. Jaboticabal: Funep, 2006. p.1-21.

GONÇALVES, E.N.; QUADROS, F.L.F. de. Morfogênese de milheto (Pennisetum americanum (L.) Leeke, em pastejo com terneiras, recebendo ou não suplementação. Ciência Rural, v.33, p.1123-1128, 2003. DOI: 10.1590/S0103-84782003000600019.

HARTMAN, L.; LAGO, R.C.A. Rapid preparation of fatty acid methyl esters from lipids. Laboratory Practice, v.22, p.475-476, 1973.

LEDOUX, M.; LALOUX, L.; WOLFF, R. Analytical methods for determination of trans-C18 fatty acids isomers in milk fat: a review. The New England Journal of Medicine, v.28, p.402-412, 2000. DOI: 10.1051/analusis:2000125.

LOOR, J.J.; UEDA, K.; FERLAY, A.; CHILLIARD, Y.; DOREAU, M. Biohydrogenation, duodenal flow, and intestinal digestion of trans fatty acids and conjugated linoleic acids in response to dietary forage: concentrate ratio and linseed oil in dairy cows. Journal of Dairy Science, v.87, p.2472-2485, 2004. DOI: $10.3168 / \mathrm{jds}$. S0022-0302(04)73372-X.

MARTÍNEZ MARÍN, A.L. Influencia de la nutrición sobre el contenido y tipo de ácidos grasos en la carne de los rumiantes. Archivos de Zootecnia, v.56, p.45-66, 2007.

MENEZES L.F.G. de; KOZLOSKI, G.V.; RESTLE, J.; BRONDANI, I.L.; PAZDIORA, R.D.; CATTELAM, J. Profile of ingested fatty acids and in the duodenal digest of steers fed different diets. Revista Brasileira de Zootecnia, v.39, p.2502-2511, 2010. DOI: $10.1590 /$ S1516-35982010001100025.

MENEZES L.F.G. de; RESTLE, J.; BRONDANI, I.L.; KOZLOSKI, G.V.; DESCHAMPS, F.; SACHET, R.H. Perfil de ácidos graxos na carne de novilhos Charolês e Nelore puros e de gerações avançadas do cruzamento rotativo, terminados em confinamento. Ciência Rural, v.39, p.2478-2484, 2009. DOI: 10.1590/S0103-84782009000800032.

MORENO, J.A. Clima do Rio Grande do Sul. Porto Alegre: Secretaria da Agricultura, 1961. 49p.

MOTT, G.O.; LUCAS, H.L. The design, conduct, and interpretation of grazing trials on cultivated and improved pastures. In: INTERNATIONAL GRASSLAND CONGRESS, 6., 1952, Pennsylvania. Proceedings. Pennsylvania: State College, 1952. p.1380-1385.

PRADO, I.N. do; MOREIRA, F.B.; MATSUSHITA, M.; SOUZA, N.E. de. Longissimus dorsi fatty acids composition of Bos indicus 
and Bos indicus x Bos taurus crossbred steers finished in pasture. Brazilian Archives of Biology and Technology, v.46, p.601-608, 2003. DOI: $10.1590 / \mathrm{S} 1516-89132003000400015$.

ROSSATO, L.V.; BRESSAN, M.C.; RODRIGUES, É.C.; GAMA, L.T. da; BESSA, R.J.B.; ALVES, S.P.A. Parâmetros físico-químicos e perfil de ácidos graxos da carne de bovinos Angus e Nelore terminados em pastagem. Revista Brasileira de Zootecnia, v.39, p.1127-1134, 2010. DOI: 10.1590/ S1516-35982010000500025.

STRECK, E.V.; KÄMPF, N.; DALMOLIN, R.S.D.; KLAMT, E.; NASCIMENTO, P.C. do; SCHNEIDER, P. Solos do Rio Grande do Sul. Porto Alegre: Emater: UFRGS, 2002. 126p.
TANAKA, K. Occurrence of conjugated linoleic acid in ruminant products and its physiological functions. Animal Science Journal, v.76, p.291-303, 2005. DOI: 10.1111/j.1740-0929.2005.00268.x.

WOOD, J.D.; ENSER, M.; FISHER, A.V.; NUTE, G.R.; SHEARD, P.R.; RICHARDSON, R.I.; HUGHES, S.I.; WHITTINGTON, F.M. Fat deposition, fatty acid composition and meat quality: a review. Meat Science, v.78, p.343-358, 2008. DOI: 10.1016/j. meatsci.2007.07.019.

WOOD, J.D.; RICHARDSON, R.I.; NUTE, G.R.; FISHER, A.V.; CAMPO, M.M.; KASAPIDOU, E.; SHEARD, P.R.; ENSER, M. Effects of fatty acids on meat quality: a review. Meat Science, v.66, p.21-32, 2004. DOI: 10.1016/S0309-1740(03)00022-6.

Received on November 13, 2012 and accepted on April 30, 2013 